\title{
QUANDO TERMINEI A GRADUAÇÃO NA FACULDADE DE DIREITO DA UNIVERSIDADE SÃO PAULO, O PROGRAMA DE PÓS-GRADUAÇÃO ME RECEBEU. DIFICULDADES E ATITUDES DE UM LUGAR PLURAL
}

\author{
Luiz Alberto David Araujo ${ }^{1}$
}

Era o ano de 1976. Eu estava no último ano da Faculdade de Direito da Universidade de São Paulo. Havia decidido mudar o turno do curso para o período noturno, para poder trabalhar. Naquela época, o último ano era dividido em áreas. Escolhi a área de Direito Público, sem muita convicção.

$\mathrm{Na}$ minha classe, havia grandes figuras, e algumas delas já se foram. Eu fazia estágio, já em fase de conclusão, na Procuradoria do Estado de São Paulo. Trabalhava com alguns Procuradores do Estado. O contato foi tão agradável que acabei seguindo a carreira, trilhando os caminhos de meu falecido pai, João Camargo de Araujo. Lá, encontrei excelentes advogados, todos muito bem-preparados, entre eles Michel Temer. Quando fui me despedir, pois o estágio estava terminando, ele me perguntou o que eu faria: "devo começar a trabalhar como advogado!" "Você devia também começar a lecionar", disse ele. "Pode me acompanhar, que eu vou ajudá-lo". Era o final de 1976.

Na opção de Direito Público, eu estudava Liberdades Públicas, Direito Municipal, Direito Eleitoral, Direito Internacional Público, entre outros temas. O curso era muito agradável, e o convívio com os professores, muito alentador. Cada um ao seu estilo, todos eram muito comprometidos com o prestígio daquela opção de quinto ano.

Eu trabalhava dando aulas em um cursinho preparatório pela manhã e, à tarde, seguia meu estágio na Procuradoria Administrativa. À noite, havia o encontro com os colegas e as aulas.

Não me recordo o mês do ano, mas, certamente, já era o final do segundo semestre quando a professora de Liberdades Públicas, que nos havia apresentado Jean Rivero, Jacques Robert, Georges Burdeau, entre outros, acabava de anunciar que as inscrições para o programa de pós-graduação em Direito estavam abertas e que deveríamos pensar na inscrição. Eram vagas para o mestrado!

Nem formado ainda eu era, e havia também o Exame da Ordem dos Advogados. Ao final da aula, nossa professora sugeriu especificamente que eu me inscrevesse. Era algo que não estava nos meus planos, porque eu tinha que começar a construir minha carreira de advogado.

O autor é mestre, doutor e livre-docente em Direito Constitucional. Foi Procurador do Estado de São Paulo e aposentou-se como Procurador Regional da República. É professor titular de Direito Constitucional da Faculdade de Direito da Pontifícia Universidade Católica de São Paulo, onde leciona desde 1983. 
Ela foi muito clara e objetiva, como sempre: "Seria bom você se inscrever, se quiser continuar seus estudos. E acho que você deve continuar".

Pensei e consultei meu pai, ainda vivo e sempre prudente. Ele me disse que, se eu quisesse esperar um pouco mais para começar a trabalhar, ele poderia me dar algum suporte. Eu agradeci (mais uma vez), mas não aceitei. Se quisesse fazer o curso, deveria também poder me sustentar.

No dia seguinte, voltei e perguntei à professora como seria a seleção. Ela disse que haveria uma prova e uma entrevista. Mas me indicou que não seria fácil, porque havia muitos inscritos, alguns mais velhos, com muita experiência e currículos excelentes. Mas que eu tinha chances e não deveria me intimidar.

Fui tentar descobrir quem eram os inscritos. Para meu desespero, consegui: muitos professores já veteranos e experientes, juízes (do então Tribunal de Alçada Civil), professores de outras instituições, desembargadores e, claro, eu, nem formado ainda. Um deles já tinha carreira consagrada em uma das melhores escolas de Direito. Só faltava-lhe o título.

E eu, repito, nem formado era ainda.

As chances eram muito pequenas, e isso para ser otimista.

Eu lia e relia meus livros de Libertés Publiques, comprados a peso de ouro na livraria que ficava atrás da faculdade. Meu francês não era ruim naquela época, até porque foram anos e anos de Aliança Francesa, um investimento sempre feito pelos meus pais.

Fui me preparando para fazer a prova e elaborar meu currículo - é claro que, à época, ainda não havia a Plataforma Lattes. No documento, procurei ressaltar que tinha alguma experiência (era difícil achar alguma experiência na minha vida aos 22 anos...) e que tinha feito um breve estágio com um dos professores da área (apesar de nunca ter desenvolvido nenhuma atividade dentro da área de Direito Constitucional enquanto isso). Juntei ao currículo meu histórico escolar. A cada etapa de montagem do currículo, mostrava os resultados para minha professora. Ela concordava, dava sugestões, mas não havia muito o que colocar no documento. Afinal...

Participei da entrevista com a professora Ada Pellegrini Grinover. Eu havia sido aluno dela enquanto estudava pela manhã nos primeiros anos da Faculdade de Direito. Ela era quem faria a seleção para Direito Constitucional, especialmente para Liberdades Públicas.

Como nunca me destaquei em Processo, a situação era apenas protocolar. Eu faria a entrevista e, certamente, o resultado estava bem claro. Acredito que, naquela época, eu já havia terminado o semestre. Fiz a melhor das entrevistas que eu podia ter feito. Estava nervoso, mas muito animado, mesmo com chances reduzidas. 
Terminei a entrevista. A professora Ada sempre foi muito gentil comigo. Ela me disse que meu currículo ainda era inconsistente e que eu era muito jovem. Não havia o que dizer. Ela estava absolutamente certa, diante de juízes do Alçada, desembargadores, professores de outras universidades da capital... Não tinha muito jeito.

Eu estava me preparando para sair da sala da entrevista quando ela me disse: "Vou falar uma coisa para você. Recebi a visita da sua professora, dizendo que você era um ótimo aluno, interessado e estudioso, e que adorava Liberdades Públicas e Direito Constitucional. Que seria uma concorrência desleal julgar pela mesma régua um jovem entusiasmado e pretensioso (o pretensioso é por minha conta) com um currículo inicial e professores já com carreira consagrada".

A professora Ada me disse que ouviu com muita atenção o que a minha professora havia lhe falado e que estava pensando. Que, na verdade, o concurso por puro mérito afastaria um grupo jovem e entusiasmado. Mas, por outro lado, não via condições de deixar de aplicar a regra proposta.

Então, antes de eu sair da sala, ela me disse: "Vou tentar reservar duas das dez vagas para os jovens que acabam de sair da faculdade. E as outras oito ficarão para os mais experientes". Sim, milagres existem! Ela ainda me disse: "Vou analisar tudo outra vez. Agora sob esse critério, de oito para duas. Parece uma forma interessante de prestigiar gente nova, interessada, e sem deixar de atender o mérito dos mais experientes".

Esse gesto foi a combinação de uma professora muito querida e dedicada, que acreditava na juventude e no entusiasmo de seus alunos, e da sabedoria da nossa querida professora Ada, que me colocou na lista. A outra figura inexperiente da lista virou presidente de um Tribunal Federal, uma juíza excelente que acabou tornando-se Desembargadora Federal.

Para mim, os 50 anos do programa de pós-graduação tem uma série de méritos e uma série de dificuldades, algo típico de programas generalistas e muito grandes. No entanto, ainda andando por ali, passando pela sala de entrevistas onde conheci o novo e recém-criado critério, não posso deixar de reconhecer que ali havia (e ainda há) uma vontade muito grande de acertar, de valorizar o entusiasmo dos mais jovens, de reconhecer jovens interessados e prestigiar, dentro do possível, as gerações mais novas. Minha professora sentiu que eu podia ser aprovado. Advogou de forma discreta em meu nome, e não me falou nada. Se não fosse o comentário da professora Ada na saída da entrevista, eu nunca teria ciência do esforço da minha professora em me recomendar e lutar por minha aprovação. Portanto, foram dois jovens recém-formados e oito excelentes candidatos que ingressaram naquela seleção.

Eu não sei se elas acertaram, mas tornei-me mestre, doutor e livre-docente. Na Faculdade de Direito da Pontifícia Universidade Católica, onde fui lecionar, fiz concursos para assistente mestre, assistente doutor, professor associado e professor titular. 
Em nenhum desses momentos deixei de reconhecer a dedicação da minha professora em permitir que eu ingressasse no mestrado naquela seleção.

Essa marca para mim é mais importante do que as excelentes avaliações recebidas pela Capes e de todos os méritos da faculdade. São gestos pequenos, mas grandiosos, de uma verdadeira professora. Provavelmente, a faculdade está cheia desses gestos, desses professores. Eu conto uma história. Mas outras tantas certamente devem existir. Outros tantos Luizes Albertos devem ter começado sua carreira dessa forma. A partir de um gesto grandioso de uma professora e do reconhecimento da entrevistadora, minha professora Ada Pellegrini Grinover. Obrigado, Universidade de São Paulo, pela oportunidade. O Programa de Pós-Graduação da Faculdade de Direito da USP deixou uma marca em minha vida. A marca da oportunidade que eu recebi e pela qual sou imensamente grato.

Depois, andei correndo mundo, terminando na minha Pontifícia Universidade Católica, onde estou há mais de 30 anos.

Provavelmente, o programa da Faculdade de Direito da USP continua oferecendo chances aos mais novos e prestigiando os mais experientes. Devem existir muitos interessados, que são capturados pela seleção, pensando nas novas gerações e investindo em novos pensamentos.

Esse processo me pareceu algo natural na época. Mas, conhecendo alguns dos professores que compõem o programa e conhecendo muitos dos alunos, não vejo como ele pode ter cessado. Provavelmente, deve estar por aí, "garimpando" gente interessada, prestigiando os alunos que se destacaram ou manifestaram interesse, cultivando esses novos alunos que são a fórmula de sucesso desse programa de pósgraduação. Eu os conheci como aluno há mais de 30 anos, e mantive contato esse tempo todo com os docentes e os alunos. Posso dizer que, entre outras qualidades, a de acompanhar, cultivar e incentivar alunos interessados pode ser uma das chaves do sucesso do programa. Parabéns. 